\title{
Gastric inhibitory polypeptide receptor: association analyses for obesity of several polymorphisms in large study groups
} Carla IG Vogel ${ }^{1}$, André Scherag ${ }^{2}$, Günter Brönner ${ }^{1,3}$, Thuy T Nguyen ${ }^{4}$, HaiJun Wang 1,5 , Harald Grallert ${ }^{6}$, Alexa Bornhorst ${ }^{7}$, Dieter Rosskopf ${ }^{7}$, Henry Völzke ${ }^{8}$, Thomas Reinehr ${ }^{9}$, Winfried Rief ${ }^{10}$, Thomas Illig ${ }^{6}, \mathrm{H}$ Erich Wichmann ${ }^{6,11}$, Helmut Schäfer ${ }^{4}$, Johannes Hebebrand ${ }^{1}$ and Anke Hinney*1

\begin{abstract}
Address: ${ }^{1}$ Department of Child and Adolescent Psychiatry, University of Duisburg-Essen, Essen, Germany, ${ }^{2}$ Institute for Medical Informatics, Biometry and Epidemiology, University Duisburg-Essen, Essen, Germany, ${ }^{3}$ Biozentrum, Universität Würzburg, Würzburg, Germany, Institute of Medical Biometry and Epidemiology, Philipps-University of Marburg, Marburg, Germany, ${ }^{5}$ Department of Maternal and Child Health, School of Public Health, Peking University, Beijing, PR China, ${ }^{6}$ Helmholtz Zentrum München - German Research Center for Environmental Health, Institute of Epidemiology, Munich-Neuherberg, Germany, ${ }^{7}$ Department Pharmacology, Center of Pharmacology and Experimental Therapy, ErnstMoritz-Arndt University Greifswald, Greifswald, Germany, ${ }^{8}$ Institute for Community Medicine, Ernst-Moritz-Arndt University Greifswald, Greifswald, Germay, ${ }^{9}$ Vestische Hospital for Children and Adolescents, University of Witten/Herdecke, Witten, Datteln, Germany, ${ }^{10}$ Department of Clinical Psychology and Psychotherapy, Philipps-University of Marburg, Marburg, Germany and ${ }^{11}$ IBE, Chair of Epidemiology, University of Munich, Munich, Germany

Email: Carla IG Vogel - carla.vogel@uni-due.de; André Scherag - andre.scherag@uk-essen.de; Günter Brönner - Guenter.Broenner@uni-due.de; Thuy T Nguyen - nguyent@med.uni-marburg.de; Hai-Jun Wang - whjun1@bjmu.edu.cn; Harald Grallert - harald.grallert@helmholtzmuenchen.de; Alexa Bornhorst - alexa_bornhorst@gmx.de; Dieter Rosskopf - rosskopf@uni-greifswald.de; Henry Völzke - voelzke@unigreifswald.de; Thomas Reinehr - T.Reinehr@kinderklinik-datteln.de; Winfried Rief - rief@staff.uni-marburg.de; Thomas Illig - illig@helmholtzmuenchen.de; H-Erich Wichmann - wichmann@helmholtz-muenchen.de; Helmut Schäfer - hsimbe@med.uni-marburg.de; Johannes Hebebrand - johannes.hebebrand@uni-due.de; Anke Hinney* - anke.hinney@uni-due.de

* Corresponding author
\end{abstract}

Published: 2 March 2009

BMC Medical Genetics 2009, 10:19 doi:10.1186/1471-2350-10-19
Received: 10 December 2008

Accepted: 2 March 2009

This article is available from: http://www.biomedcentral.com/147/-2350/10/19

(C) 2009 Vogel et al; licensee BioMed Central Ltd.

This is an Open Access article distributed under the terms of the Creative Commons Attribution License (http://creativecommons.org/licenses/by/2.0), which permits unrestricted use, distribution, and reproduction in any medium, provided the original work is properly cited.

\begin{abstract}
Background: Gastric inhibitory polypeptide (GIP) is postulated to be involved in type 2 diabetes mellitus and obesity. It exerts its function through its receptor, GIPR. We genotyped three GIPR SNPs (rs8III428, rs2302382 and rs 1800437) in German families with at least one obese index patient, two case-control studies and two cross-sectional population-based studies.

Methods: Genotyping was performed by MALDI-TOF, ARMS-PCR and RFLP. The family-study: 76I German families with at least one extremely obese child or adolescent $(n=I, 04 I)$ and both parents $(n=1,522)$. Case-control study: (a) German obese children $(n=333)$ and (b) obese adults $(n=987)$ in comparison to 588 adult lean controls. The two cross-sectional population-based studies: KORA $(n=8,269)$ and SHIP $(n=4,310)$.

Results: We detected over-transmission of the A-allele of $r s 2302382$ in the German families (PTDT-Test $=0.0089)$. In the combined case-control sample, we estimated an odd ratio of 1.54 $(95 \% \mathrm{Cl} \quad 1.09 ; 2.19$, PCA-Test $=0.014)$ for homozygotes of the $\mathrm{rs} 2302382 \mathrm{~A}$-allele compared to individuals with no A-allele. A similar trend was found in KORA where the rs2302382 A-allele led
\end{abstract}


to an increase of $0.12 \mathrm{BMI}$ units $(p=0.136)$. In SHIP, however, the A-allele of rs2302382 was estimated to contribute an average decrease of $0.27 \mathrm{BMI}$ units $(\mathrm{p}$-value $=0.03 \mathrm{I}$ ).

Conclusion: Our data suggest a potential relevance of GIPR variants for obesity. However, additional studies are warranted in light of the conflicting results obtained in one of the two population-based studies.

\section{Background}

Obesity is a serious health problem in both developed and in developing countries. It results from an interplay of environmental and genetic factors that mediate energy intake and expenditure. From twin studies it is estimated that up to $80 \%$ of the variance in body mass index (BMI) might be genetically determined [1-4]. These genetic contributions seem to be especially important in individuals with severe or early-onset forms of obesity [5]. The molecular mechanisms of obesity are still far from being well understood.

It has been suggested that the gastric inhibitory polypeptide (GIP) may be involved in type 2 diabetes mellitus and obesity [6-8]. GIP, also known as glucose-dependent insulinotropic peptide, is a gastrointestinal hormone of 42 amino acids secreted by endocrine $\mathrm{K}$ cells from the duodenum in response to meal ingestion, especially for meal containing fat or glucose [7,9]. The principal action of GIP is the stimulation of glucose-dependent insulin secretion [10]. Obesity leads to insulin resistance and excessive insulin secretion after meal ingestion [11]. Plasma GIP concentrations are elevated in obese and diabetic humans and also in leptin deficient $(o b / o b)$ rodents [11].

Variables that can lead to a dysfunction or act as antagonists of GIP have been shown to reduce obesity and insulin resistance [12]. Daily administration of GIP antagonists, such as ( Pro $^{3}$ )GIP, has been able to promote weight loss and ameliorate insulin resistance in mice $[11,13]$. Obese patients subjected to bariatric surgery, that involves bypass of part of the small intestine, and consequently reduction of GIP secretion, presented restoration of normal glucose tolerance prior to weight loss [14].

GIP exerts its function through its specific receptor, GIPR. Inactivation of GIPR results in a defective GIP signaling [15]. Under normal diet, GIPR knockout mice (Gipr/-) do not exhibit changes in body weight but have reduced fat mass compared with wild type (WT) mice [16,17], and normal levels of glucose and insulin [6]. Under high fat diet Gipr-- mice, in comparison to WT mice, have a reduced fat storage; they use fat as the main energy substrate and do not develop obesity, insulin resistance, diabetes mellitus, impaired glucose tolerance, and fatty liver like the WT $[6,7,15-18]$. Additionally, GIP signaling is required for effective accumulation of nutrients under high-fat diet, and inhibition of GIP signaling not only prevents obesity but also insulin resistance [19]. Recently, a study in mice [20] showed that vaccination against GIP prevents its binding to the GIP receptor, consequently reducing body weight gain under high fat diets. Nitz et al. [21] showed preliminary evidence for nominal association of a non-synonymous GIPR polymorphism (rs1800437) and cardiovascular disease (CVD).

Taken together, these observations show the importance of GIP signaling for fat storage rendering GIPR an interesting candidate for obesity. In order to investigate whether polymorphisms within the coding or adjacent regions of the GIPR gene are associated with obesity, we genotyped three single nucleotide polymorphisms (SNP) pertaining to the gene in up to 761 German obesity families comprising at least one extremely obese child or adolescent and both parents. These SNPs include a coding non-synonymous, conservative SNP in exon 12 (rs1800437 G/C; Glu354Gln), an intronic SNP (rs2302382 C/A in intron 1 ), and a SNP in the putative promoter region (rs8111428 $\mathrm{A} / \mathrm{G}$ ). These SNPs tag common variation of the gene (see details below). Subsequently, we attempted to validate our results in four independent German samples (two case-control studies and two cross-sectional populationbased studies).

\section{Methods \\ Characterization of Study Subjects}

BMI was calculated as weight in kilograms and divided by height in squared meters. Children and adolescents with a BMI over the $90^{\text {th }}$ age and gender specific BMI percentile were considered overweight and children and adolescents with $\mathrm{BMI}$ at or over $97^{\text {th }}$ percentile were considered obese [22]. In adults, overweight was defined as BMI $\geq 25 \mathrm{~kg} / \mathrm{m}^{2}$, obesity as $\mathrm{BMI} \geq 30 \mathrm{~kg} / \mathrm{m}^{2}$ [23].

\section{Subjects \\ Obesity families}

The sample consisted of German obese children, adolescents $\left(72 \%\right.$ had a $\mathrm{BMI} \geq 99^{\text {th }}$ percentile, [22]) and their parents recruited at the Universities of Marburg and Duisburg-Essen. For the family-based association analyses we genotyped 1,041 obese children and adolescents and 1,522 of their parents (Table 1). 
Table I: Characteristics of participants used for family-based association, case-control and cross-sectional population-based samples in GIPR analyses.

\begin{tabular}{|c|c|c|c|c|c|}
\hline & sub-group & n participants & $\operatorname{sex}(M / F)$ & mean age $(y) \pm S D$ & mean BMI $(\mathrm{kg} / \mathrm{m})^{2} \pm \mathrm{SD}$ \\
\hline \multirow[t]{3}{*}{ Group } & parents & 1,522 & $76 I / 761$ & $42.55 \pm 5.96$ & $30.37 \pm 6.28$ \\
\hline & children & $|, 04|$ & $477 / 564$ & $|3.88 \pm 3.7|$ & $31.11 \pm 6.05^{1,2}$ \\
\hline & obese children and & & & & \\
\hline \multirow[t]{4}{*}{ case-control } & adolescents & 336 & $153 / 183$ & $10.74 \pm 2.75$ & $28.29 \pm 4.8 I^{\prime}$ \\
\hline & obese adults & 987 & $361 / 626$ & $46.31 \pm 14.74$ & $36.03 \pm 5.39$ \\
\hline & underweight and normal & & & & \\
\hline & weight controls & 588 & $235 / 353$ & $25.28 \pm 4.41$ & $19.34 \pm 1.94$ \\
\hline \multirow[t]{2}{*}{ KORA S3/S4 } & $\mathrm{BMI} \geq 30 \mathrm{~kg} / \mathrm{m}^{2}$ & $\mathrm{I}, 849$ & $876 / 973$ & $54.47 \pm 0.29$ & $33.58 \pm 0.08$ \\
\hline & $\mathrm{BMI}<30 \mathrm{~kg} / \mathrm{m}^{2}$ & 6,420 & $3,267 / 3,153$ & $47.92 \pm 0.17$ & $25.23 \pm 0.04$ \\
\hline \multirow[t]{2}{*}{ SHIP } & $\mathrm{BMI} \geq 30 \mathrm{~kg} / \mathrm{m}^{2}$ & 1,099 & $53 \mid / 568$ & $54.90 \pm 14.34$ & $33.55 \pm 3.29$ \\
\hline & $\mathrm{BMI}<30 \mathrm{~kg} / \mathrm{m}^{2}$ & 3,201 & $1,582 / 1,619$ & $48.04 \pm 16.69$ & $25.13 \pm 2.94$ \\
\hline
\end{tabular}

Iall had a BMI $\geq$ the age and gender normalized $90^{\text {th }}$ percentile [22]

$272 \%$ even had a BMI $\geq$ the age and gender normalized $99^{\text {th }}$ percentile [22]

\section{Case-control studies}

Cases: (A) 987 German obese (BMI $\geq 30 \mathrm{~kg} / \mathrm{m}^{2}$ ) adults from a study at the University of Marburg sampled in the region of Marburg, Germany [24] (Table 1) and (B) 336 overweight and obese children and adolescents (all had a $\mathrm{BMI} \geq 90^{\text {th }}$ percentile) recruited within the Obeldicks program [25] at the University of Witten/Herdecke in the region of Datteln, Germany (Table 1). Controls: 588 normal and underweight healthy (all had $\mathrm{BMI}<75^{\text {th }}$ percentile) adults who were students at the University of Marburg at the time of recruitment (Table 1, [24]). The use of lean adults who were never overweight or obese during childhood (assessed by interview [26]), as control group reduces the chances of misclassification compared to the use of lean children as controls who might become overweight in adulthood.

\section{KORA}

(Kooperative Gesundheitsforschung im Raum Augsburg, Surveys 3 and 4, Cooperative Health Research in the Region of Augsburg) is a cross-sectional population-based sample of 8,269 German adult individuals from the region of Augsburg (Bavaria, Germany) [27]. In KORA, $65.9 \%$ of all participants were overweight and $22.4 \%$ obese (Table 1) according to the WHO definition.

\section{SHIP}

(Study of Health in Pomerania) is a cross-sectional population-based survey from the Northeastern area of Germany comprising 4,310 adult German individuals. SHIP was designed to address general health and community medicine issues, with endocrine-metabolic disorders as a main focus. In SHIP, $65.8 \%$ of all participants were overweight and $25.5 \%$ obese (Table 1 ) according to the WHO definition.
All participants gave written informed consent and in the case of minors, their parents. The studies were approved by the local Ethical Committees and in case of KORA by the Landesärztekammer Bavaria.

\section{Genotyping and SNPs selection}

We selected tagging SNPs (or proxy) for the two linkage disequilibrium (LD) blocks covering the coding region and the 5 ' region $(24 \mathrm{~Kb})$ of GIPR.

Genotyping the families for the SNPs rs2302382 and rs8111428 was performed using Matrix-assisted desorption/ionization time-of-flight mass spectrometry (MALDI-TOF MS) as described earlier [28]. SNP rs1800437 (a) was genotyped using polymerase chain reaction restriction fragment length polymorphism (PCRRFLP) analysis. Additional genotypes for SNPs rs 2302382 (b) and rs8111428 (c) were performed using ARMS-PCR as described previously (16): (a) rs1800437: F 5'-ATT ACC GGC TGA GGT GAG G-3' and R 5'-CTG GAA GGA GCT GAG GAA GA-3' digested with BssSI (C-allele 245 bp, Gallele 150 and $94 \mathrm{bp}$ ). (b) rs2302382: $\mathrm{F}_{\mathrm{o}}$ 5'-CAG CGT AGC TCT AGG GCA ACC GCC CGC T-3' and $\mathrm{R}_{\mathrm{o}}$ 5'-GAT $^{\prime}$ CAG GCC TGG AGG GTC CCA GGG CAA G-3':324 bp; $F_{i}$ 5'-CCA CTC CGC GTG CCT CTC CCT CCT CC-3' and $\mathrm{R}_{\mathrm{i}}$ 5'-CCG CAA CTC CCA GGC GTG ATG ATC CGT-3' (Callele $200 \mathrm{bp}$, A-allele $177 \mathrm{bp}$ ). (c) rs8111428: $\mathrm{F}_{\mathrm{o}}$ 5'-AAA GGA ACA GAC TGG AAG TAG AGA CAG-3' and $\mathrm{R}_{\mathrm{o}} 5^{\prime}$-TTT ATG ACA CAA GCT GAA AGT CAC AC-3':486 bp; $\mathrm{F}_{\mathrm{i}}$ 5'- $^{\prime}$ TGT ATA TGA CTG TAT GTG ACT TGT GAC TG-3' and $\mathrm{R}_{\mathrm{i}}$ 5'-CAC AAC TCT CCC TTA GTC TCA CCA AT-3' (G-allele $258 \mathrm{bp}$, A-allele $283 \mathrm{bp}$ ). All call rates were $\geq 99 \%$; except for rs 2302382 for the obese children and adolescents and for SHIP were the call rates were $\geq 90 \%$. 


\section{In silico analysis of GIPR polymorphisms}

Possible alterations in splicing sites were analysed using GeneScan [29]. Potential functions were analysed using the FastSNP program [30].

\section{Statistical analysis}

All genotype distributions were tested for deviations from Hardy Weinberg equilibrium (exact two-sided p-value $>0.14$ ). For the coding SNP rs1800437 the p-value for HWE in the parents (family study) was 0.035 . Thus, we regenotyped a 96-well plate for this SNP to exclude false genotyping results; the results were $100 \%$ identical to the initial data, thus reducing the chance of genotyping errors. Single marker family-based association analyses were carried out using the pedigree disequilibrium test (PDT-average) while FAMHAP (Version 16, [31]) and UNPHASED (Version 2.404, using the EM algorithm [32]) were used to investigate haplotypes in families. Case-control association analyses were performed using the exact or asymptotic Cochran-Armitage trend test with a linear trend or Fishers exact test for crude allele frequency comparisons. Correspondingly, BMI in KORA and SHIP were investigated by linear regression analyses assuming an additive genetic model with age and sex as covariates. Power calculations were done with the software QUANTO Version 1.2.3 [33] for common variants assuming a minor allele frequency MAF of 0.2 and $\alpha=0.05$ (two-sided). For both the family-based approach (761 trio families) and the validation sample of 1,323 cases and 588 controls the power estimates were larger than $80 \%$ to detect a log-additive genotype relative risk of 1.3 . For the quantitative analyses in both population-based studies, the power estimate was larger than $80 \%$ to detect a standardized additive effect of 0.08 . Thus, all samples were well powered to detect at least moderate to strong effect sizes of disease predisposing variants.

Confidence intervals were calculated with coverage of 95\% (abbreviated 95\%CI) and accordingly the level $\alpha$ for each test was 0.05 (two-sided). Unless otherwise stated all reported p-values are nominal, two-sided and not adjusted for multiple testing.

\section{Results}

\section{Initial family-based association studies}

We performed family-based association analyses in up to 2,563 German Caucasian individuals from 761 families.
The analyses indicated some evidence for transmission disequilibrium for the investigated markers in particular for the G-allele of rs8111428 (p-value $=0.0016)$ and the A-allele of rs2302382 (p-value $=0.0089)$, both minor alleles (Table 2). In addition, for the non-synonymous SNP rs1800437, we observed a trend for the G-allele (major allele) to be more frequently transmitted to the obese offspring ( $\mathrm{p}=0.076$; Table 2$)$. To explore if a single SNP or a haplotype was involved in obesity we further analysed haplotype structure in the gene region using the CEU population data from the International HapMap Project [34] captured by Haploview software [35] (solid spine algorithm). There are two regions of increased between-marker LD (Figure 1). The first covers $24 \mathrm{~kb}$ and the second $5 \mathrm{~kb}$. For the two markers showing the strongest signals in our study, rs8111428 and rs2302382, there are no direct HapMap data available. However, their physical positions indicate that they could be part of the first haplotype block, as confirmed when using our family data in Haploview (data not shown). For the SNP, rs1800437, LD HapMap data was available indicating that this SNP belongs to the second region which was supported by our family data (data not shown). The pairwise $\mathrm{r}^{2}$ values between the SNPs (using our family data) are shown in Table 3. Subsequently, we performed analyses of the transmitted haplotypes (Table 4). One haplotype (estimated frequency $=21 \%$ ) that included the minor alleles of rs8111428 (G-allele) and rs2302382 (A-allele), was more frequently transmitted in the families $(p=0.003)$. Testing all haplotype combinations this haplotype had the smallest adjusted p-value of 0.0055 which is corrected for multiple testing. As the haplotype analysis revealed that no haplotype by itself leads to a stronger association signal, we decided to validate the best initial SNPs results.

\section{Validation studies in case-control samples and in cross- sectional population-based samples}

To confirm the exploratory results we attempted to validate these results by case-control studies in obese adults, children, and adolescents compared to healthy normal and underweight controls. Furthermore, genotyping was done in two cross-sectional population-based samples.

The initially determined risk-allele (A) of rs2302382 was more frequent in obese children $(23.8 \%)$ and adults $(22.4 \%)$ than in the controls $(19.1 \%$; p pishers exact test $=$ 0.013). Using the log-additive genetic model in the joint

Table 2: Results of the family-based association analyses for GIPR SNPs in families with severely obese offspring

\begin{tabular}{|c|c|c|c|c|c|c|c|}
\hline SNP & physical position & n genotyped families & localization & risk-allele & transmitted ${ }^{\prime}$ & non- transmitted & p-value \\
\hline & & & Putative & & & & \\
\hline rs8 I I I 428 & 50859941 & 579 & promoter & G & 403 & 329 & 0.0016 \\
\hline rs23023082 & 50864409 & 541 & Intron I & A & 395 & 329 & 0.0089 \\
\hline rs I 800437 & 50873232 & 761 & Exon 12 & G & 1,644 & 1,599 & 0.0760 \\
\hline
\end{tabular}

las derived from PDT 
Table 3: Linkage disequilibrium (LD)' between GIPR SNPs of the study using the family data.

\begin{tabular}{ccc}
\hline & $r s 8111428^{2}$ & $r s 2302382$ \\
\hline$r s 2302382^{2}$ & 0.71 & - \\
$r s 1800437^{3}$ & 0.039 & 0.039
\end{tabular}

I values are given in pairwise $r^{2}$

2 No LD information in HapMap

${ }^{3} \mathrm{rs} \mid 800437$ is the only proxy SNP for $r s$ II $672660\left(r^{2}=1.0\right)$

analyses of all cases against the control group, we e.g. estimated that individuals homozygous for the A-allele have an 1.54-fold increase in the odds for obesity compared with individuals not carrying the A-allele $(95 \% \mathrm{CI}$ $\left.1.09 ; 2.19, \mathrm{p}_{\text {CA-Test }}=0.014\right)$. The estimated odds ratio for the heterozygous CA carriers was 1.24 (95\%CI 1.04;1.48, Table 5). When the children were analysed separately, the odds ratios were descriptively larger than those observed for the joint analyses.

Additionally, although for the non-synonymous SNP rs1800437 the major risk allele was prima vista more frequent in obese children (78.7\%) and adults (79.6\%) than in the controls $(77.5 \%)$, there was no significant difference in allele or genotype distributions ( $\mathrm{p}_{\text {Fishers exact test }}=$ 0.395; p $_{\text {CA-Test }}=0.219$ ) (Table 5).

The cross-sectional population-based samples KORA and SHIP were both genotyped for SNP rs2302382. In KORA, the regression analyses showed a trend for the presence of one A-allele to lead to an average increase of $0.12 \mathrm{BMI}$ units $(95 \%$ CI $-0.04 ; 0.28$; p-value $=0.136)$ (Table 6). Similarly, stratification by WHO BMI categories underlined this trend ( $\mathrm{p}_{\mathrm{CA}-\mathrm{Test}}$ asy $=0.037$ for the comparison of $\mathrm{BMI}<$ 30 vs. BMI $\geq 30$ ). In SHIP, however, the effect of the Aallele pointed into the opposite direction. In contrast to all previous findings, the A-allele of rs2302382 was estimated to decrease mean BMI units by $0.27 \mathrm{~kg} / \mathrm{m}^{2}(95 \% \mathrm{CI}$ $-0.52 ;-0.24 ; \mathrm{p}$-value $=0.031 ; \mathrm{p}_{\text {CA-Test } \text { asy }}=0.039$ for the comparison of $\mathrm{BMI}<30$ vs. $\mathrm{BMI} \geq 30 \mathrm{~kg} / \mathrm{m}^{2}$ ).

\section{Predictions of putative functional consequences of GIPR polymorphisms}

The intronic SNP rs2302382 was analysed for alternative splice sites (using GeneScan) caused by the base change, but no respective alterations were found. No known function was found in FastSNP for rs2302382.

The non-synonymous SNP Glu354Gln (rs1800437) is located in a transmembrane domain of GIPR [21]. Analysis of the SNP rs1800437 using FastSNP showed that the predicted altered protein has a low to medium risk to be damaging (ranking 2-3; whereby 5 is the maximum risk). This tool predicts that the respective mutation $\mathrm{G} / \mathrm{C}$ creates an additional exonic splicing enhancer in the sequence comprising the C-allele.

\section{Discussion}

We provide evidence for an association of polymorphisms in and near the GIPR gene with obesity or increased BMI. We performed family-based association tests in up to 761 German nuclear families with severely obese offspring. The haplotype analyses in the genotyped region indicated the presence of two distinct regions of increased linkage disequilibrium (LD): first, a putative regulatory region for GIPR comprising SNPs rs8111428 and rs2302382 and second, a region covering the GIPR coding region comprised SNP rs1800437.

Evidence for association with obesity was found for the SNPs in the putative regulatory region of GIPR. In nuclear families, we observed an increased transmission rate for the minor alleles of rs8111428 (G-allele) and rs2302382 (A-allele) to the obese offspring, indicating the presence of a possible risk haplotype for obesity. Further analyses in two independent samples of cases and one control sample underlined and validated this association. In two large population-based cross-sectional samples of adults, however, the results were ambiguous. While we observed a similar trend for rs2302382 in KORA (> 8,000 individuals) where the risk allele was related to an increased BMI, the same risk allele was inversely associated with BMI in SHIP.

Table 4: GIPR haplotype analyses in families with severely obese offspring using UNPHASED (Version 2.404; using the EM algorithm) and FAMHAP (Version 16)

\begin{tabular}{ccccccc}
\hline rs8III428 & rs2302382 & rs I800437 & transmitted & non- transmitted & $\begin{array}{c}\text { estimated } \\
\text { frequency of the haplotype }\end{array}$ \\
\hline A & A & G & 18.02 & 30.01 & 0.04 & 0.179 \\
A & C & G & 325.20 & 326.90 & 0.57 & 0.16 \\
A & C & C & 103.80 & 129.10 & 0.21 & 0.054 \\
G & A & G & $\mathbf{1 2 3 . 8 0}$ & $\mathbf{8 6 . 1 0}$ & 0.003 \\
G & A & C & 7.20 & 6.90 & 0.02 & 0.179 \\
G & C & G & 8.00 & 7.00 & 0.179 \\
\hline
\end{tabular}

The risk haplotype is marked in bold 


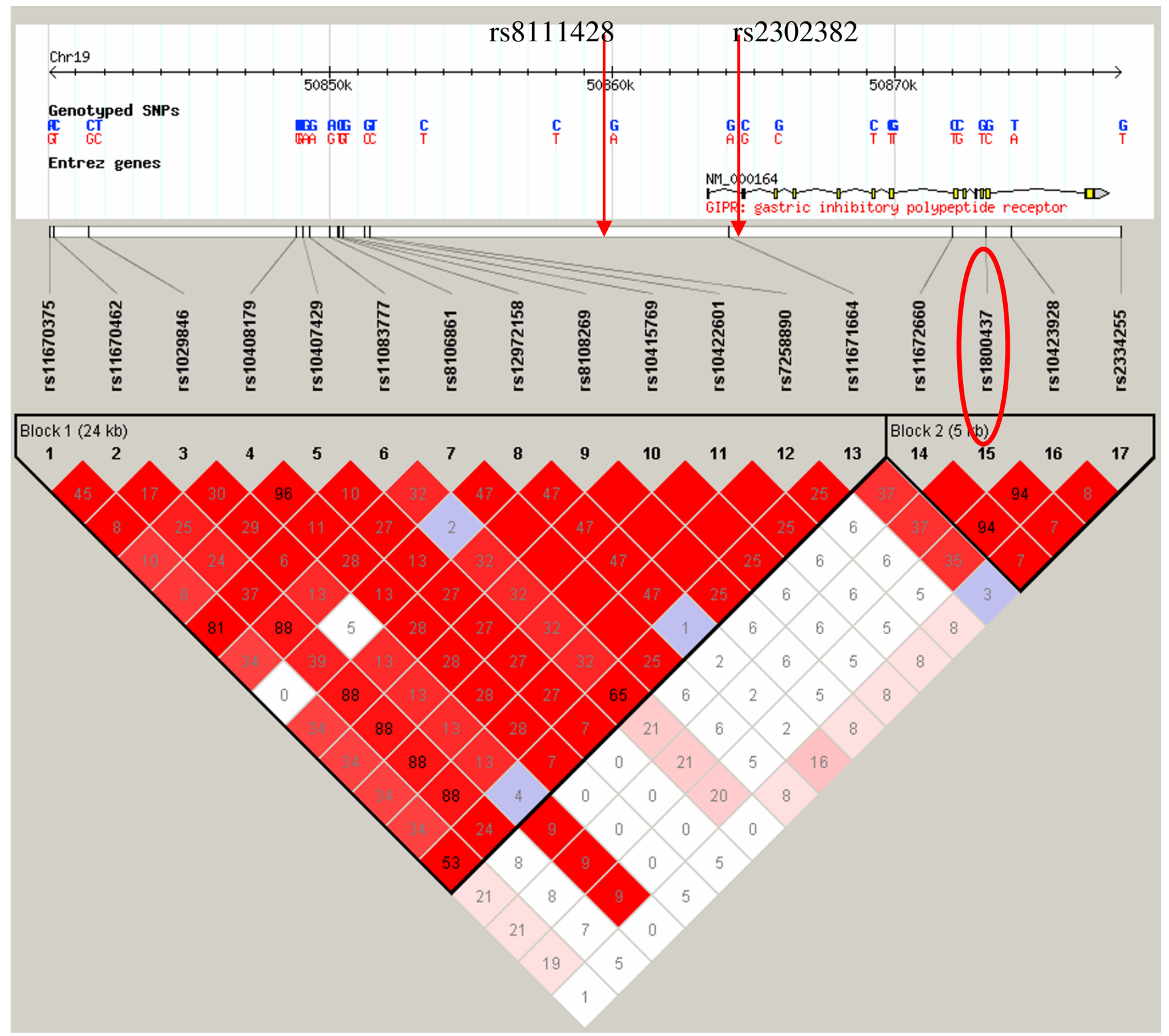

\section{Figure I}

LD structure of GIPR. LD structure of GIPR region using data from HapMap analysed by Haploview using the Spine LD algorithm. Only SNP rs 1800437 is informative as LD in HapMap (ellipse). The physical localization for the other two SNPs (rs8I I 428 and rs2302382) was represented manually with arrows. The pairwise $r^{2}$ values are represented in the diamonds.

Analyses of the putative regulatory region of GIPR were previously performed in patients with Cushing syndrome, which is associated with obesity [36,37]. There were no significant differences in genotype frequencies between patients and controls [36]. Our family and case-control data suggested an increased obesity risk with an estimated odds ratio of 1.54 for individuals with two copies of the risk A-allele at SNP rs2302382 in the putative regulatory region. Since this SNP was not directly analysed in previous reports [36,37], functional studies are warranted. All participants were recruited in Germany, for which popu- lation stratification effects have shown to be of minor importance under a case-control design [38].

Additionally, in the second LD region we found a trend for the G-allele of rs 1800437 to be more frequently transmitted to obese children. The same allele was also more frequently detected in obese cases than in controls (Tables 2 and 5).

Despite all evidence for the involvement and importance of GIPR in obesity, until now few studies analysed variants 
Table 5: Genotype and case-control analyses for three GIPR SNPs

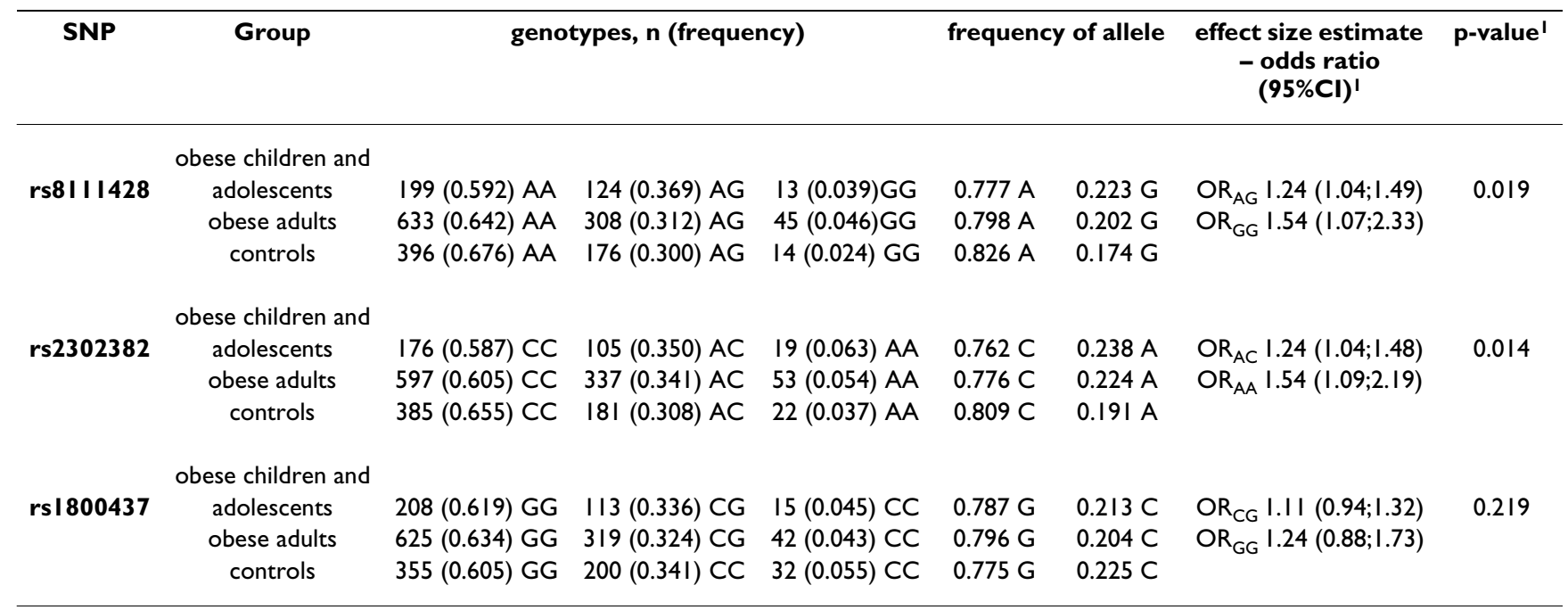

\footnotetext{
I exact Cochran-Armitage trend test (assuming a linear trend) not corrected for age and sex where all obese individuals were pooled; separate comparison of adults and children against the controls revealed no substantially different results
}

in GIPR and their risk for obesity. Some studies involving the non-synonymous variant rs1800437 did not reveal association with increased BMI [21,39] or to non-insulindependent diabetes $[39,40]$. However, in one study, Cpeptide concentrations in serum of homozygous individuals for the C-allele (minor allele) of rs 1800437 were significantly decreased (14\%) after fasting [39]. Additionally, association with lower cholesterol levels was found in heterozygous individuals with CVD [21]. Thus, the results of both studies (Lower C-peptide concentrations [39] and lower cholesterol levels [21]) are in line with our case-control study where the C-allele was more frequent in controls than in cases. Additionally, in our German obesity families, we found a trend of the G-allele (major allele) to be more frequently transmitted to severely obese offspring $(p=0.076)$. Taken together, these results suggest an association of the G-allele of rs 1800437 with obesity. If a dysfunctional GIPR receptor leads to a lower fat mass we have to assume that obesity would be associated with gain of function mutations. Hence, we assume a gain of function for the G-allele of non-synonymous SNP rs1800437 and the respective risk alleles of the
SNPs in the putatively regulatory region (rs2302382 and rs8111428) which might alter transcription binding sites causing an increased gene expression. Investigations with independent and large samples are necessary to validate our observed associations. Samples from the extremes of the phenotype would be the best choice. Once an even more robust signal is obtained, re-sequencing as well as functional studies will be necessary to elucidate the functional role of the GIPR variants.

GIPR is located at the region on chromosome $19 \mathrm{q} 13$ that was reported to have highly differentiated SNPs showing strong geographical variation within the English population [41]. KORA and SHIP are population-based samples with individuals from Southern and Northern Germany. A similar effect as in the English population it could, at least in theory, account for the discrepant result in SHIP. An exploration of differences in genotype frequencies of rs2302382 in KORA and SHIP, irrespective of phenotype, indicated that this might be the case $(\mathrm{p}=0.035)$. Additionally, there are multiple phenotypic variables which differ between KORA and SHIP; examples are hyperten-

Table 6: Genotype results for GIPR SNP rs2302382 in the population-based cohorts KORA and SHIP

\begin{tabular}{|c|c|c|c|c|c|c|c|c|}
\hline \multirow[t]{2}{*}{ Group } & & \multicolumn{3}{|c|}{ genotypes, n (frequency) } & \multicolumn{2}{|c|}{ Allele frequency } & \multirow[t]{2}{*}{ effect size estimate $(95 \% \mathrm{Cl})^{\prime}$} & \multirow[t]{2}{*}{ p-value ${ }^{\prime}$} \\
\hline & & CC & CA & AA & C & $A$ & & \\
\hline \multirow[t]{2}{*}{ KORA } & $\mathrm{BMI} \geq 30 \mathrm{~kg} / \mathrm{m}^{2}$ & $\mathrm{I}, \mathrm{I} 03(0.597)$ & $644(0.348)$ & $102(0.055)$ & 0.771 & 0.229 & $\beta_{A} 0.12$ & 0.136 \\
\hline & $\mathrm{BMI}<30 \mathrm{~kg} / \mathrm{m}^{2}$ & $3,993(0.622)$ & $2,117(0.330)$ & $310(0.048)$ & 0.787 & 0.213 & $(-0.04 ; 0.28)$ & \\
\hline \multirow[t]{2}{*}{ SHIP } & $\mathrm{BMI} \geq 30 \mathrm{~kg} / \mathrm{m}^{2}$ & $645(0.640)$ & $332(0.329)$ & $3 \mathrm{I}(0.03 \mathrm{I})$ & 0.805 & 0.195 & $\begin{array}{c}\beta_{\mathrm{A}}-0.27 \\
(-0.52 ;-0.24)\end{array}$ & 0.031 \\
\hline & $\mathrm{BMI}<30 \mathrm{~kg} / \mathrm{m}^{2}$ & $\mathrm{I}, 842(0.622)$ & $995(0.336)$ & $126(0.042)$ & 0.790 & 0.210 & & \\
\hline
\end{tabular}

I linear regression under an additive genetic model (risk-allele A) corrected for age and sex, two-sided p-value 
sion [42] or smoking behaviour [43], which could also account for the different genotypic effect.

It might seem surprising that GIPR has not been detected in any of the currently published genome-wide association studies on obesity (BMI) [e.g. [26,44-48]]. There are at least two explanations: First, genome-wide SNP chips do not cover well the region of GIPR. For example, the Affymetrix Genome-Wide Human SNP 6.0 Array (with more than 906,600 SNPs) in the region $\pm 50 \mathrm{~Kb}$ of GIPR only comprises 3 SNPs and none of these SNPs is within GIPR. The Illumina $580 \mathrm{~K}$ array on the other hand comprises 19 SNPs in the region $\pm 50 \mathrm{~Kb}$ of GIPR, but only three of them are within the gene. One idea would be to use imputation analyses to solve this problem. Imputations, however, heavily rely on just a few HapMap individuals and the assumption that linkage disequilibrium between markers is the same for these individuals and the individuals actually genotyped. Moreover, for markers like rs8111428 and rs2302382 there is no HapMap information available making imputations impossible. Second, current meta-analyses of genome-wide association studies did focus on BMI in the general population; it might well be that GIPR variants have a major impact in extremes of the phenotype only.

\section{Conclusion}

In conclusion, our data provide a first step towards identification of GIPR variants potentially involved in obesity. Most likely variations in the putative regulatory region of the gene (e.g. rs2302382) are the most promising candidates for independent validations in case-control samples or in selected family samples as well as ultimately in functional studies. If our findings indeed are truly positive, this study also supports the observation $[26,49]$ that cross-sectional population-based studies seem to be less powerful to detect obesity-marker associations as they are rarely enriched with extremely obese individuals.

\section{Competing interests}

The authors declare that they have no competing interests.

\section{Authors' contributions}

CIGV participated of the study design, perform the genotyping and drafted the manuscript; AS participated of the study design, performed statistical analysis and drafted the manuscript. TTN performed statistical analysis. $\mathrm{AB}$ and HG performed genotyping. GB, HJW, DR, HV, TR, WR, TI, and HEW participated of the study design; JH and $\mathrm{AH}$ conceived the study, participated in its design and coordination and drafted the manuscript. All authors read and approved the final manuscript.

\section{Acknowledgements}

We thank all the participants of this study. We also thank the valuable technical assistance of Jitka Andrä and Sieglinde Düerkop. This work was sup- ported by grants from the German Ministry of Education \& Research (BMBF, NGFN2 and NGFNplus: 0 IGS0820, 01 GS0830 and 01 GS0823 and OIGS08197), the German Research Foundation (DFG: HE I446/4-I,2) and the European Union (FP6 LSHMCT-2003-50304I). SHIP is part of the Community Medicine Research net http://ship.community-medicine.de of the University of Greifswald, Germany, which is funded by the BMBF (grant no. ZZ9603), the Ministry of Cultural Affairs as well as the Social Ministry of the Federal State of Mecklenburg-West Pomerania.

\section{References}

I. Friedel S, Reichwald K, Scherag A, Brumm H, Wermter AK, Fries HR, Koberwitz K, Wabistch M, Meitinger T, Platzer M, Biebermann H, Hinney $A$, Hebebrand $\mathrm{J}$ : Mutation screen and association studies in the Diacylglycerol O-acyltransferase homolog $\mathbf{2}$ gene (DGAT2), a positional candidate gene for early onset obesity on chromosome I I q I3. BMC Genet 2007, 8: I7.

2. Brönner G, Erdmann J, Mayer B, Hinney A, Hebebrand J: Genetic factors for overweight and CAD. Herz 2006, 3 I: I89-I99.

3. Barsh GS, Farooqi IS, O'Rahilly SO: Genetics of body-weight regulation. Nature 2000, 404:644-5I.

4. Ahima RS, Osei SY: Molecular regulation of eating behaviour: new insights and prospects for therapeutic strategies. Trends Mol Med 200I, 7(5):205-2I3.

5. Swarbrick MM, Waldenmaier B, Pennacchio LA, Lind DL, Cavazos MM, Geller F, Merriman R, Ustaszewska A, Malloy M, Scherag A Hsueh WS, Rief W, Mauvais-Jarvis F, Pullinger CR, Kane JP, Dent R, McPherson R, Kwok PY, Hinney A, Hebebrand J, Vaisse C: Lack of support for the association between GAD2 polymorphisms and severe human obesity. PloS Biol 2005, 3(9):e3 15.

6. Miyawaki K, Yamada Y, Ban N, Ihara Y, Tsukiyama K, Zhou H, Fujimoto S, Oku A, Tsuda K, Toyokuni S, Hiai H, Mizunoya W, Fushiki T, Holst J, Makino M, Tashita A, Kobara Y, Tsubamoto Y, Jinnouchi T, Jomori T, Seino $Y$ : Inhibition of gastric inhibitory polypeptide signalling prevents obesity. Nat Med 2002, 8(7):738-74.

7. Ballinger A: Gastric inhibitory polypeptide links overnutrition to obesity. Gut 2007, 52(3):319-320.

8. Flatt PR: Dorothy Hodgkin lecture 2008 Gastric inhibitory polypeptide (GIP) revisited: a new therapeutic target for obesity-diabetes? Diabetic Medicine 2008.

9. Miyawaki K, Yamada Y, Yano H, Niwa H, Ban N, lhara Y, Kubota A, Fujimoto S, Kajikawa M, Kuroe A, Tsuda K, Hashimoto H, Yamashita T, Jomori T, Tashiro F, Miyazaki Jl, Seino Y: Glucose intolerance caused $b$ a defect in the entero-insular axis: A study in gastric inhibitory polypeptide receptor knockout mice. Proc Natl Acad Sci USA 1999, 96(26): | 4843-| 4847.

10. Drucker DJ: The role of gut hormones in glucose homeostasis. J Clin Invest 2007, I I 7( I):24-32.

II. McClean PL, Irwin N, Cassidy RS, Holst JJ, Gault VA, Flatt PR: GIP receptor antagonism reverses obesity, insulin resistance, and associated metabolic disturbances induced in mice by prolonged consumption of high-fat diet. Am J Physiol Endocrinol Metab 2007, 293:EI746-EI755.

12. Irwin N, K'Hunter K, Flatt PR: Comparison of the metabolic effects of GIP receptor antagonism and PYY(3-36) receptor. Peptides 2007.

13. Irwin N, McClean PL, O'Harte FPM, Gault VA, Harriot P, Flatt PR: Early administration of the glucose-dependent insulinotropic polypeptide receptor antagonist (Pro $\left.{ }^{3}\right)$ GIP prevents the development of diabetes and related metabolic abnormalities associated with genetically inherited obesity in ob/ ob mice. Diabetologia 2007, 50:1532-1540.

14. Flatt PR: Effective surgical treatment of obesity may be mediated by ablation of the lipogenic gut hormone gastric inhibitory polypeptide (GIP): evidence and clinical opportunity for development of new obesity-diabetes drugs? Diab Vasc Dis Res 2007, 4(2): I50-152.

15. Harada N, Yamada Y, Tsukiyama K, Yamada C, Nakamura Y, Mukai E, Hamasaki A, Liu $X$, Toyoda $K$, Seino $Y$, Inagaki N: A novel GIP receptor splice variant influences GIP sensitivity of pancreatic $\beta$-cells in mice. Am J Physiol Endocrinol Metab 2008, 294:E6I-E68.

16. Yamada Y, Seino Y: Physiology of GIP - A Lesson from GIP receptor knockout mice. Horm Metab Res 2004, 36:77I-774. 
17. Hansotia T, Maida A, Flock G, Yamada Y, Tsukiyama K, Seino Y, Drucker DJ: Extrapancreatic incretin receptors modulate glucose homeostasis, body weight, and energy expenditure. J Clin Invest 2007, II 7:143-152.

18. Yamada C, Yamada Y, Tsukiyama K, Yamada K, Yamane S, Harada N, Miyawaki K, Seino Y, Inagaki N: Genetic inactivation of GIP signalling reverses aging-associated insulin resistance through body composition changes. Biochem Biophys Res Commun 2007, 364: $175-180$.

19. Zhou H, Yamada Y, Tsukiyama K, Miyawaki K, Hosokawa , Nagashima K, Toyoda K, Naitoh R, Mizunoya W, Fushiki T, Kadowaki T, Seino Y: Gastric inhibitory polypeptide modulates adiposity and fat oxidation under diminished insulin action. Biochem Biophys Res Commun 2005, 335:937-942.

20. Fulurija A, Lutz TA, Sladko K, Osto M, Wielinga PY, Bachmann MF, Saudan P: Vaccination against GIP for the treatment of obesity. PLOS ONE 2008, 3(9):e3163.

21. Nitz I, Fisher E, Weikert C, Burwinkel B, Li Y, Möhlig M, Boeing H, Schreiber S, Schrezenmeir J, Döring F: Association analyses of GIP and GIPR polymorphisms with traits of the metabolic syndrome. Mol Nutr Food Res 2007, 5 I: I 046-1052.

22. Hebebrand J, Heseker H, Himmelmann GW, Schäfer H, Remschmidt $\mathrm{H}$ : Altersperzentilen für den Body Mass Index aus Daten der Nationalen Verzehrsstudie einschließlich einer Übersicht zu relevanten Einflußfaktoren. Aktuel Ernährungsmed 1994, 19:259-265.

23. WHO: [http://www.who.int/mediacentre/factsheets/fs31//en/ index.html].

24. Hinney A, Bettecken T, Tarnow P, Brumm H, Reichwald K, Lichtner P, Scherag A, Nguyen TT, Schlumberger P, Rief W, Vollmert C, Illig T, Wichmann HE, Schäfer H, Platzer M, Biebermann H, Meitinger T, Hebebrand J: Prevalence, spectrum and functional characterization of melanocortin 4 receptor gene mutations in a representative population-based sample and obese adults from Germany. J Clin Endocrinol Metab 2006, 9 I(5): I76|-69.

25. Reinehr T, Hinney A, de Sousa G, Austrup F, Hebebrand J, Andler W: Definable somatic disorders in overweight children and adolescents. J Pediatrics 2007, I 50:618-622.

26. Hinney A, Nguyen TT, Scherag A, Friedel S, Brönner G, Müller TD, Grallert H, Illig T, Wichmann HE, Rief W, Schäfer H, Hebebrand J: Genome Wide Association (GWA) Study for early onset extreme obesity supports the role of Fat Mass and Obesity Associated Gene (FTO) variants. PLOS ONE 2007, 2( I 2):e I 36 I.

27. Wichmann HE, Gieger C, Illig T, MONICA/KORA Study Group: KORA-gen-resource for population genetics, controls and a broad spectrum of disease phenotypes. Gesundheitswesen 2005, 67(Suppl I):S26-S30

28. Ye S, Dhillon S, Ke X, Collins AR, Day IN: An efficient procedure for genotyping single nucleotide polymorphisms. Nucleic Acids Res 2001, 29:E88-8.

29. The New GENSCAN Web Server at MIT [http:// genes.mit.edu/GENSCAN.html]

30. Fast SNP: A Functional Analysis and Selection Tool for SNP in Large Scale Association Study. [http://fast snp.ibms.sinica.edu.tw/pages/input CandidateGeneSearch.jsp].

31. Becker T, Knapp M: A powerful strategy to account for multiple testing in the context of haplotype analysis. Am J Hum Genet 2004, 75:561-70.

32. Dudbridge F: Likelihood-based association analysis for nuclear families and unrelated subjects with missing genotype data. Hum Hered 2008, 66(2):87-98.

33. Gene X Environment, Gene $\mathbf{X}$ Gene Interaction Homepage [http://hydra.usc.edu/gxe]

34. International HapMap Project [http://www.hapmap.org]

35. Broad Institute [http://www.broad.mit.edu/mpg/haploview/ index.php]

36. Antonini SR, N'Diaye N, Baldacchino V, Hamet P, Tremblay J, Lacroix $A$ : Analysis of the putative regulatory region of the gastric inhibitory polypeptide receptor gene in food-dependent Cushing's syndrome. I Steroid Biochem Mol Biol 2004, 9 I: I 7 I-I 77.

37. Baldacchino V, Oble S, Décarie PO, Bourdeau I, Hamet P, Tremblay J, Lacroix A: The Sp transcription factors are involved in the cellular expression of the human glucose-dependent insulinotropic polypeptide receptor gene and overexpressed in adrenals of patients with Cushing's syndrome. J Mol Endocrinol 2005, 35:6|-7|.
38. Steffens M, Lamina C, Illig T, Bettecken T, Vogler R, Entz P, Suk EK, Toliat MR, Klopp N, Caliebe A, König IR, Köhler K, Ludemann J, Diaz Lacava A, Fimmers R, Lichtner P, Ziegler A, Wolf A, Krawczak M, N\&\#x0 I6B;rnberg P, Hampe J, Schreiber S, Meitinger T, Wichmann HE, Roeder K, Wienker TF, Baur MP: SNP-based analysis of genetic substructure in the German population. Hum Hered 2006, 62(I):20-9.

39. Almind K, Ambye L, Urhammer SA, Hansen T, Echwald SM, Holst JJ, Gromada J, Thorens B, Pedersen O: Discovery of amino acid variants in the human glucose-dependent insulinotropic polypeptide (GIP) receptor: the impact on the pancreatic beta cells responses and functional expression studies in Chinese hamster fibroblast cells. Diabetologia I 998, 4 I: I I 94- I I 98.

40. Kubota A, Yamada Y, Hayami T, Yasuda K, Someya Y, Ihara Y, Kagimoto S, Watanabe R, Taminato T, Tsuda K, Seino Y: Identification of two missense mutations in the GIP receptor gene: a functional study and association analysis with NIDDM: no evidence of association with Japanese NIDDM subjects. Diabetes 1996, 45( I 2): | 701- I705.

4I. The Wellcome Trust Case Control Consortitum: Genome-wide association study of 14,000 cases of seven common disease and 3,000 shared controls. Nature 2007, 447(7 I 45):66I-678.

42. Meisinger $C$, Heier $M$, Völzke $H$, Löwel $H$, Mitusch $R$, Hense HW Lüdemann J: Regional disparities of hypertension prevalence and management within Germany. Journal of Hypertension 2006 , 24(2):293-299.

43. Völzke H, Neuhauser H, Moebus S, Baumert J, Berger K, Stang A, Ellert U, Werner A, Döring A: Rauchen: regionale Unterschied in Deutschland. Deutsches Ärzteblatt 2006, I03(42):A2784-A2790.

44. Meyre D, Delplanque J, Chèvre JC, Lecoeur C, Lobbens S, Gallina S, Durand E, Vatin V, Degraeve F, Proença C, Gaget S, Körner A, Kovacs P, Kiess W, Tichet J, Marre M, Hartikainen AL, Horber F, Potoczna N, Hercberg S, Levy-Marchal C, Pattou F, Heude B, Tauber M, McCarthy MI, Blakemore AIF, Montpetit A, Polychronakos C, Weill J, Coin LJM, Asher J, Elliott $P$, Järvelin MR, Visvikis-Siest S, Balkau B, Sladek R, Balding D, Walley A, Dina C, Froguel P: Genome-wide association study for early-onset and morbid adult obesity identifies three new risk loci in European populations. Nat Genet 2009.

45. Willer CJ, Speliotes EK, Loos RJ, Li S, Lindgren CM, Heid IM, Berndt SI, Elliott AL, Jackson AU, Lamina C, Lettre G, Lim N, Lyon HN, McCarroll SA, Papadakis K, Qi L, Randall JC, Roccasecca RM, Sanna S, Scheet P, Weedon MN, Wheeler E, Zhao JH, Jacobs LC, Prokopenko I, Soranzo N, Tanaka T, Timpson NJ, Almgren P, Bennett A, Bergman RN, Bingham SA, Bonnycastle LL, Brown M, Burtt NP, Chines P, Coin L, Collins FS, Connell JM, Cooper C, Smith GD, Dennison EM, Deodhar P, Elliott P, Erdos MR, Estrada K, Evans DM, Gianniny L, Gieger C, Gillson CJ, Guiducci C, Hackett R, Hadley D, Hall AS, Havulinna AS, Hebebrand J, Hofman A, Isomaa B, Jacobs KB, Johnson T, Jousilahti P, Jovanovic Z, Khaw KT, Kraft P, Kuokkanen M, Kuusisto J, Laitinen J, Lakatta EG, Luan J, Luben RN, Mangino M, McArdle WL, Meitinger T, Mulas A, Munroe PB, Narisu N, Ness AR, Northstone K, O'Rahilly S, Purmann C, Rees MG, Ridderstråle M, Ring SM, Rivadeneira F, Ruokonen A, Sandhu MS, Saramies ], Scott LJ, Scuteri A, Silander K, Sims MA, Song K, Stephens J, Stevens S, Stringham HM, Tung YC, Valle TT, Van Duijn CM, Vimaleswaran KS, Vollenweider P, Waeber G, Wallace C, Watanabe RM, Waterworth DM, Watkins $N$, Wellcome Trust Case Control Consortium, Witteman JC, Zeggini E, Zhai G, Zillikens MC, Altshuler D, Caulfield MJ, Chanock SJ, Farooqi IS, Ferrucci L, Guralnik JM, Hattersley AT, Hu FB, Jarvelin MR, Laakso M, Mooser V, Ong KK, Ouwehand WH, Salomaa V, Samani NJ, Spector TD, Tuomi T, Tuomilehto J, Uda M, Uitterlinden AG, Wareham NJ, Deloukas P, Frayling TM, Groop LC, Hayes RB, Hunter DJ, Mohlke KL, Peltonen L, Schlessinger D, Strachan DP, Wichmann HE, McCarthy MI, Boehnke M, Barroso I, Abecasis GR, Hirschhorn JN, Genetic Investigation of ANthropometric Traits Consortium: Six new loci associated with body mass index highlight a neuronal influence on body weight regulation. Nat Genet 2009 , 4 I (I):25-34.

46. Scuteri A, Sanna S, Chen WM, Uda M, Albai G, Strait J, Najjar S, Nagaraja $R$, Orrú $M$, Usala $G$, Dei M, Lai S, Maschio A, Busonero F, Mulas $A$, Ehret GB, Fink AA, Weder AB, Cooper RS, Galan P, Chakravarti A, Schlessinger D, Cao A, Lakatta E, Abecasis GR: Genome-Wide association scan shows genetic variants in the FTO gene are associated with obesity-related traits. PLoS Genet 2007, 3:e I I 5.

47. Herbert A, Gerry NP, McQueen MB, Heid IM, Pfeufer A, Illig T, Wichmann HE, Meitinger T, Hunter D, Hu FB, Colditz G, Hinney A, Hebe- 
brand J, Koberwitz K, Zhu X, Cooper R, Ardlie K, Lyon H, Hirschhorn JN, Laird NM, Lenburg ME, Lange C, Christman MF: A Common genetic variant is associated with adult and childhood obesity. Science 2006, 3 | 2:279-283.

48. Thorleifsson G, Walters GB, Gudbjartsson DF, Steinthorsdottir V, Sulem P, Helgadottir A, Styrkarsdottir U, Gretarsdottir S, Thorlacius S, Jonsdottir I, Jonsdottir T, Olafsdottir EJ, Olafsdottir GH, Jonsson T, Jonsson F, Borch-Johnsen K, Hansen T, Andersen G, Jorgensen T, Lauritzen T, Aben KK, Verbeek AL, Roeleveld N, Kampman E, Yanek LR, Becker LC, Tryggvadottir L, Rafnar T, Becker DM, Gulcher J, Kiemeney LA, Pedersen O, Kong A, Thorsteinsdottir U, Stefansson K: Genome-wide association yields new sequence variants at seven loci that associate with measures of obesity. Nat Genet 2009, 4 I (I): 18-24.

49. Frayling TM, Timpson NJ, Weedon MN, Zeggini E, Freathy RM, Lindgren CM, Perry JRB, Elliott KS, Lango H, Rayner NW, Shields B, Harries LW, Barett JC, Ellard S, Groves C], Knight B, Patch AM, Ness AR, Ebrahim S, Lawlor DA, Ring SM, Ben-Shlomo Y, Jarvelin MR, Sovio U, Bennet AJ, Melzer D, Ferrucci L, Loos RJF, Barroso I, Wareham NJ, Karpe F, Owen KR, Cardon LR, Walker M, Hitman GA, Palmer CAN Doney ASF, Morris AD, Davey-Smith G, The Wellcome Trust Case Control Consortium, Hattersley AT, McCarthy MI: A common variant in the FTO gene is associated with body mass index and predisposes to childhood and adult obesity. Science 2007, 31 6:889-894.

\section{Pre-publication history}

The pre-publication history for this paper can be accessed here:

http://www.biomedcentral.com/1471-2350/10/19/pre pub

Publish with Bio Med Central and every scientist can read your work free of charge

"BioMed Central will be the most significant development for disseminating the results of biomedical research in our lifetime. "

Sir Paul Nurse, Cancer Research UK

Your research papers will be:

- available free of charge to the entire biomedical community

- peer reviewed and published immediately upon acceptance

- cited in PubMed and archived on PubMed Central

- yours - you keep the copyright 